\section{Longitudinal Study on the Lifestyle and Health of University Students (ELESEU): design, methodological procedures, and preliminary results}

\section{Estudo Longitudinal sobre Estilo de Vida e Saúde em Estudantes Universitários (ELESEU): delineamento, procedimentos metodológicos e resultados preliminares}

\section{Longitudinal sobre el Estilo de Vida y la Salud} de Estudiantes Universitarios (ELESEU): diseño, procedimientos metodológicos, y resultados preliminares
QUESTÕES METODOLÓGICAS

METHODOLOGICAL ISSUES
Patrícia Simone Nogueira 1

Márcia Gonçalves Ferreira 1

Paulo Rogério Melo Rodrigues 1

Ana Paula Muraro 2

Lídia Pitaluga Pereira 2

Rosangela Alves Pereira 3

doi: 10.1590/0102-311X00145917

\begin{abstract}
Admission to a university may cause significant changes in the pattern of exposure to health risks. The aim of this paper is to describe the study design and methodological procedures adopted in the Longitudinal Study on the Lifestyle and Health of University Students (ELESEU). This study examines a dynamic cohort of full-time students at a public university in the State of Mato Grosso, Brazil. This research, which started in 2015, will have four years of follow-up and is scheduled to end in 2018. A self-administered questionnaire is applied, containing questions regarding demographic and socioeconomic characteristics, and information on health conditions and risk factors such as lifestyle, perceived stress, symptoms of depression, body image, risk behaviors for eating disorders, self-assessment of health and diet quality, and other issues related to nutrition and health. Anthropometric and blood pressure measurements are also recorded. Two 24-hour dietary recalls and cholesterol, triglycerides, and glucose capillary measurements are collected in 50\% of the students. In 2015, 495 participants (82.6\% of the eligible students) were assessed in the baseline study. Of these, 348 (70.3\%) were followed up in 2016. In 2016, 566 participants were included in the cohort (81\% of the eligible students). This study will help to identify the factors that might influence changes in the nutritional, health, and metabolic status of young adults during college life.
\end{abstract}

Students; Universities; Life Style; Longitudinal Studies

\author{
Correspondence \\ P. S. Nogueira \\ Faculdade de Nutrição, Universidade Federal de Mato Grosso. \\ Av. Fernando Corrêa da Costa 2367, Cuiabá, MT \\ 78060-900, Brasil. \\ patricianogueira.ppj@gmail.com \\ 1 Faculdade de Nutrição, Universidade Federal de Mato Grosso, \\ Cuiabá, Brasil. \\ 2 Instituto de Saúde Coletiva, Universidade Federal de Mato \\ Grosso, Cuiabá, Brasil. \\ 3 Departamento de Nutrição Social e Aplicada, Universidade \\ Federal do Rio de Janeiro, Rio de Janeiro, Brasil.
}




\section{Introduction}

According to the Brazilian Institute of Geography and Statistics (IBGE) 1, in the last ten years there has been a significant increase in the number of young people aged 18 to 24 years attending college. The estimate is that $58.5 \%$ of the individuals in this age group had enrolled at college in 2014.

Starting college life implies in challenges and lifestyle modifications. Among these challenges, the separation from family and friends, increased independence and responsibility, lack of adult supervision, academic requirements, and development of new social networks are worth highlighting. These conditions, as well as the introduction to an unfamiliar environment, lead to exposure to several health risks 2 .

Such changes may lead to the adoption of less healthy behaviors, including inappropriate eating habits, reduced physical activity, increased sedentary behavior, alcohol consumption, smoking, and changes in sleep habits 3,4,5,6. Those behaviors have often been associated with an increased risk of metabolic disorders and the development of chronic non-communicable diseases such as obesity, cardiovascular diseases, diabetes mellitus type 2 , and cancer 7,8,9. In addition, students are likely to maintain those unhealthy behaviors throughout their lives 10 . Thus, college students must be viewed as a group that requires special attention regarding health promotion, especially healthy eating.

Other aspects that must be considered are the changes in metabolic profile that may result from weight gain and unhealthy lifestyle behaviors. Undesirable changes in blood glucose, lipid profile, and blood pressure have an immediate and lasting impact on the development of cardiovascular diseases 11,12. In a study conducted with Colombian college students, it was observed the beginning of college life was marked by changes in serum levels of lipids, with decreased high-density and low-density lipid cholesterol and triglycerides, as well as the elevation of blood pressure 13.

In national studies, it was verified that college students have increased levels of stress, unhealthy eating habits, changes in sleep patterns, and reduced physical activity. Given such context, the university food environment has been considered unfavorable to healthy eating 14,15. This environment can function as a barrier to healthy eating, given the low access to and small variability of healthy food options, and higher prices for these options when compared to regular ones 16,17. A systematic review described 15 studies that evaluated interventions performed in university food environments to improve eating behavior. Among those, 13 presented positive effects regarding nutrition, with improved eating habits and increased purchase of healthy foods 18 .

Overall, college life involves intense changes in the life of individuals, with adverse repercussions on their health, including in weight and metabolic profile. However, longitudinal studies exploring behavioral changes during college life in comparison to those habits practiced during high school are scarce. In this sense, the Longitudinal Study on the Lifestyle and Health of University Students (ELESEU) is developed with the aim to evaluate changes in lifestyle, health, and nutrition conditions, and the metabolic profile of students during university life.

This article presents the study design and methodological procedures adopted in the ELESEU. Furthermore, it describes the sample characteristics in the first and second stages of data collection (2015 and 2016).

\section{Study design and population}

This research examines a dynamic cohort of college students through annual census surveys during the academic calendar. It assesses students enrolled in full-time courses at the Mato Grosso Federal University (UFMT), campus Cuiabá, Mato Grosso State, Brazil. This study will have four years of follow-up; it was launched in 2015 and is scheduled to end in 2018. Within this period, all selected students will be examined and reassessed annually (Figure 1).

The study population consists of students aged up to 25 years entering full-time courses in the first semester of each academic year between 2015 and 2018. Subjects with the following characteristics are to be excluded from this study: students with physical disabilities that limit the performance of anthropometric measurements, pregnant or who are breastfeeding, who have previously acquired a university degree, distance learning students, and those selected to enter the university in the second semester. 
Schematic representation of the follow-up process with the dynamic cohort of university students entering full-time courses at the Mato Grosso Federal University, Cuiabá Campus, Brazil. Longitudinal Study on Lifestyle and Health of University Students (ELESEU).

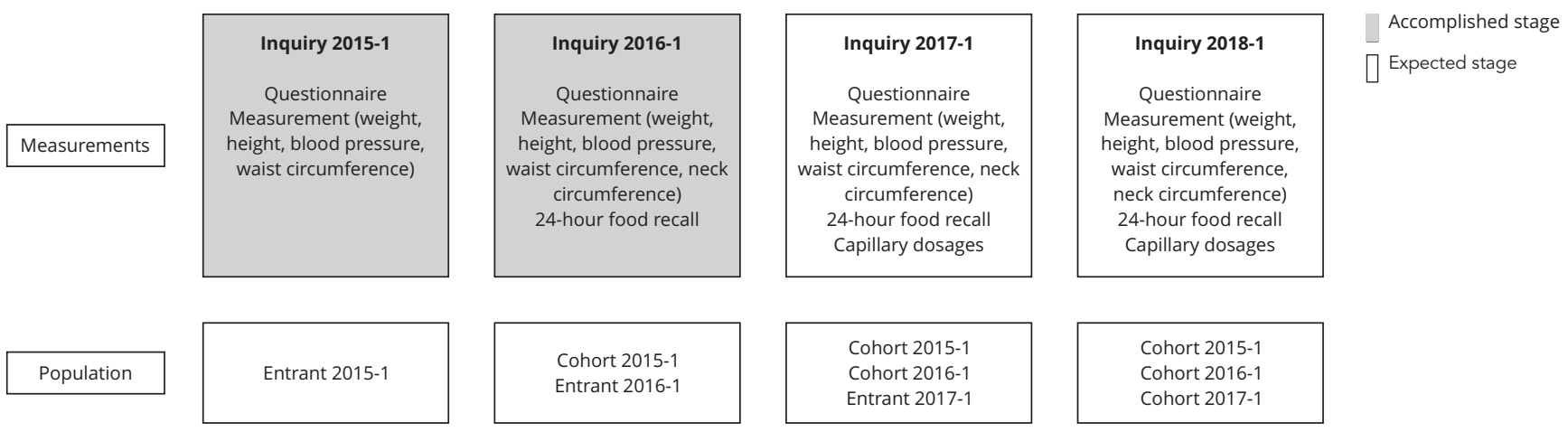

In 2015, when the study began, the UFMT, campus Cuiabá, offered 60 undergraduate courses, in which there were 10,403 students enrolled 19. The 21 courses being offered on full-time basis were identified and grouped according to the type of academic degree, that is, bachelor's degree (Agronomy, Architecture and Urban Planning, Computer Science, Biology, Nursing, Civil Engineering, Electrical Engineering, Forest Engineering, Sanitary and Environmental Engineering, Physics, Geology, Medicine, Veterinary Medicine, Nutrition, Psychology, Chemistry, and Zootechnics), and teaching certification (Biology, Philosophy, Mathematics, and Chemistry).

The Ethics Research Committee, the Júlio Müller University Hospital, and the UFMT approved this research under the protocol n. 1.006 .048 on 31st March 2015. An Informed Consent Form had to be signed by each student before performing data collection. Students were informed about the importance of checking their nutritional status and blood pressure, and advised to seek medical attention if any abnormalities were found. The study was approved by the administrative instances and courses of the university in which there is data collection.

\section{Data collection}

The Academic Information Management System of UFMT was used to obtain a list with the registration numbers and names of the students entering in the first semester and of those in each follow-up. This procedure will be adopted every year to identify eligible subjects for the study. Data collection is to be scheduled in each class according to available dates, under the guidance of the field interviewers. For students absent at the time of data collection, strategies to locate them such as phone call, e-mail, and social network contacts are adopted to set an appointment for conducting the survey. In these cases, up to 6 contact attempts are made. If the students are not found or show no interest in participating in the research, they will be considered as losses to follow-up and refusals, respectively.

Data are being collected through a self-administered questionnaire, in the classroom, at previously scheduled times. After completing this step, students have their anthropometric measurements taken. They also have their blood pressure and blood tests done, and are finally asked to complete a 24-hour dietary recall (24hR).

Data collection is conducted by undergraduate and postgraduate students, under supervision of the researchers responsible for the project. The interviewers had previously been trained on the questionnaire completion, the $24 \mathrm{hR}$ application, taking anthropometrical measurements, checking blood pressure, and performing blood tests. A manual was prepared to support the training and to 
guide the interviewers about the proper way to approach interviewees, ethical issues, and filling out the form. A pilot study for standardization and testing the fieldwork coordination was carried out in a class not included in the research.

The questionnaires are scrutinized during data collection by the research coordinators, to minimize mistakes during the filling out of the questionnaire. When incomplete, incomprehensible, or inconsistent questionnaires are detected, the interviewee is contacted via phone, e-mail, or social network to clarify doubts. Data are entered twice into Epi Info version 7 (Centers for Disease Control and Prevention, Atlanta, USA), a software that enables validation strategy to find inconsistencies.

\section{Measurement procedures}

A self-administered questionnaire is being used to obtain information on demographics, socioeconomic data, and on conditions, diseases, and risk factors such as lifestyle characteristics, perception of stress, depression symptoms, body image perception, risk behaviors for eating disorders, selfassessment of health, quality of diet, and nutrition and health-related issues. All questions are detailed in Table 1.

\section{- Demographic and socioeconomic data}

The following socioeconomic and demographic variables were considered: age, sex, race/color of skin 20 , type of high school attended, with whom they lived at the time of research, and existence of internet at home.

To assess socio-economic class, the Economic Classification Criteria of the Brazilian Population Studies is used. This categorization 21 is based on the possession of durable consumer goods, educational level of the head of the family, and access to public services (such as paved streets and running water). All this information concerns the students' family home. Based on this assessment, the individual is classified into five economic classes. Parents' education is also an independent variable, classified into three categories according to the number of study years (Table 1).

\section{- Food consumption and food-related habits}

The food consumption of college students is being assessed by screening questions, included in the general questionnaire on dietary habits and consumption of healthy and risky eating markers such as the consumption of visible fat in meat and chicken skin, use of artificial sweeteners, and habits of sugar and salt added. Additionally, factors that influence food selection are identified by choosing from a 15-item list 22,23 the 3 most important and 3 less important reasons in picking food, as well as the products consumed while watching television, playing video games, or using the computer.

Meal consumption habits are also evaluated (breakfast, morning snack, lunch, afternoon snack, dinner, and supper), being assessed how often (times per week) and where the students have each meal. Such questions are also posed about the year prior to entering the university. It is also verified the frequency of having breakfast, lunch, and dinner at a University Restaurant.

Diet restriction practices before and after going to college are assessed; in addition, diet quality self-assessment is obtained by the question: "How do you rate the quality of your diet?".

Furthermore, in a sub-sample with 50\% of the college students, two $24 \mathrm{hR}$ are applied on nonconsecutive days, to provide an estimate of the habitual food consumption on weekdays and weekends. For the application of $24 \mathrm{hR}$ the multi-step method 24 is adopted.

\section{- Physical activity and sedentary behaviors}

The condensed version of the International Physical Activity Questionnaire (IPAQ), adapted and validated for Brazil, was applied in this study 25. The IPAQ is being applied for the year prior and after entering university. Sedentary habits are assessed by specific questions regarding the number of hours spent watching TV, using the computer, playing video games, and using the cell phone. The classification of sedentary habits will be based on the criterion proposed by Hickman et al. 26 . 
Table 1

Information obtained in the questionnaire administered to the students enrolled on the Longitudinal Study on the Lifestyle and Health of University Students (ELESEU).

\begin{tabular}{|c|c|c|c|}
\hline Type of information & Method/Variables & Categories & Reference \\
\hline \multirow[t]{3}{*}{ Demographic data } & Age & Years & \\
\hline & Gender & Male/female & \\
\hline & IBGE/Race-skin color & White, black, mulatto (pardo), Asian, Native & IBGE 20 \\
\hline \multirow[t]{5}{*}{ Socioeconomic data } & Administrative category of high school & $\begin{array}{l}\text { Federal public school, state public school, } \\
\text { municipal public school, or private school }\end{array}$ & \\
\hline & Currently resides with & Alone, parents, relatives, or other & \\
\hline & Access to the internet at home & Yes or no & \\
\hline & ABEP/Economic class & $\begin{array}{c}A, B, C, D-E \text {, with " } A \text { " being the highest and } \\
\text { "D-E," the lowest }\end{array}$ & ABEP 21 \\
\hline & Parents' level of education & $\begin{array}{c}<9 \text { years (incomplete elementary school), } \\
9 \text { to } 12 \text { years (complete elementary school/ } \\
\text { incomplete high school), and > } 12 \text { years } \\
\text { (complete high school) }\end{array}$ & \\
\hline \multirow[t]{10}{*}{$\begin{array}{l}\text { Food consumption and food-related } \\
\text { habits }\end{array}$} & Screening & Healthy and unhealthy eating habits markers & $\begin{array}{c}\text { Secretaria } \\
\text { de Vigilância } \\
\text { em Saúde, } \\
\text { Ministério da } \\
\text { Saúde } 52\end{array}$ \\
\hline & $\begin{array}{l}\text { Factors that influence food consumption } \\
\text { are identified }\end{array}$ & $\begin{array}{l}\text { Aspects, and sensory, cultural, social, } \\
\text { economic, and alimentary habits }\end{array}$ & $\begin{array}{l}\text { Kearney } \\
\text { et al. } 22 \\
\text { Estima } 23\end{array}$ \\
\hline & $\begin{array}{l}\text { Products consumed while watching } \\
\text { television, playing video games or using } \\
\text { the computer * }\end{array}$ & List of 10 products & \\
\hline & Frequency of meals consumption * & $\begin{array}{c}\text { Daily, 5-6 times/week, 3-4 times/week, 1-2 } \\
\text { times/week and never/almost never }\end{array}$ & \\
\hline & Place of meals consumption * & $\begin{array}{l}\text { Usually does not eat, at home, at school/ } \\
\text { university, snack bar, bar-restaurant, others }\end{array}$ & \\
\hline & Diet practice & Yes or no & \\
\hline & & $\begin{array}{l}\text { List of } 10 \text { activities performed to lose or gain } \\
\text { weight }\end{array}$ & \\
\hline & $\begin{array}{l}\text { Frequency of meals consumption at the } \\
\text { University Restaurant }\end{array}$ & $\begin{array}{c}6 \text { times/week, } 5 \text { times/week, } 4 \text { times/week, } 3 \\
\text { times/week, } 2 \text { times/week, } 1 \text { time/week and } \\
\text { never/almost never }\end{array}$ & \\
\hline & Diet & Very good, good, regular, bad, and very poor & \\
\hline & $24 \mathrm{hR}$ & & $\begin{array}{l}\text { Conway } \\
\text { et al. } 24\end{array}$ \\
\hline \multirow[t]{2}{*}{$\begin{array}{l}\text { Physical activity and sedentary } \\
\text { behaviors }\end{array}$} & IPAQ/Physical activity level * & $\begin{array}{l}\text { Very active, active, insufficiently active ( } a \text { and } \\
\text { b), sedentary }\end{array}$ & $\begin{array}{l}\text { Matsudo } \\
\text { et al. } 25\end{array}$ \\
\hline & Sedentary habits & $\begin{array}{c}3 \text { hours or more/day as excessive computer } \\
\text { use, and } 4 \text { hours or more/day as excessive } \\
\text { use of television }\end{array}$ & $\begin{array}{l}\text { Hickman } \\
\text { et al. } 26\end{array}$ \\
\hline
\end{tabular}

(continues) 
Table 1 (continued)

\begin{tabular}{|c|c|c|c|}
\hline Type of information & Method/Variables & Categories & Reference \\
\hline Consumption of alcoholic beverages & Experimentation & Age; or never experienced & \\
\hline \multirow[t]{10}{*}{ and smoking } & Consumption in the last 30 days * & Days/Month & Moura \& \\
\hline & & & Malta 27 \\
\hline & Abusive alcohol consumption in the last & Days/Month & Moura \& \\
\hline & 30 days & & Malta 27 \\
\hline & Intake of ethanol in the last 7 days & Grams & $\begin{array}{l}\text { Ferreira et } \\
\text { al. } 28\end{array}$ \\
\hline & Current smoking & Days/Month & WHO 29 \\
\hline & Time of exposure to tobacco & & $\begin{array}{l}\text { Reichert et } \\
\text { al. } 30\end{array}$ \\
\hline & Number of cigarettes smoked/day & & $\begin{array}{l}\text { Reichert et } \\
\text { al. } 30\end{array}$ \\
\hline & $\begin{array}{l}\text { Use of tobacco and alcohol in the year } \\
\text { prior to admission in the university * }\end{array}$ & Yes/No & \\
\hline & $\begin{array}{c}\text { Drink at least one dose of alcoholic } \\
\text { beverage }\end{array}$ & Days/Month & \\
\hline \multirow[t]{2}{*}{$\begin{array}{l}\text { Body image and self-perception of } \\
\text { weight status }\end{array}$} & Appearance-healthy & List of 9 figures & $\begin{array}{l}\text { Stunkard } \\
\text { et al. } 44\end{array}$ \\
\hline & Self-perception of weight condition & $\begin{array}{l}\text { Above normal, normal, below normal, } \\
\text { do not know }\end{array}$ & \\
\hline \multirow[t]{3}{*}{ Assessment of sleeping habits } & Hours of sleep * & & \\
\hline & ESE-BR/Disorders & Excessive daytime sleepiness & $\begin{array}{l}\text { Bertolazi } \\
\text { et al. } 45\end{array}$ \\
\hline & PSQI-BR/Habits-quality & $\begin{array}{l}\text { Hours, minutes, none in the last month, less } \\
\text { than once/week, } 1 \text { or } 2 \text { times/week, } 3 \text { or } \\
\text { more times/week }\end{array}$ & $\begin{array}{l}\text { Bertolazi } \\
\text { et al. } 46\end{array}$ \\
\hline \multirow[t]{2}{*}{ Emotional stress and depression } & Perception of stress & $\begin{array}{l}\text { Never, almost never, sometimes, fairly often, } \\
\text { very often }\end{array}$ & Reis et al. 47 \\
\hline & PHQ-9/Depression episodes & $\begin{array}{l}\text { Not once, several days, more than half the } \\
\text { days, almost everyday }\end{array}$ & $\begin{array}{l}\text { Santos } \\
\text { et al. } 48\end{array}$ \\
\hline Disordered eating habits & $\begin{array}{c}\text { Binge eating } \\
\text { methods of weight control or gain } \\
\text { compensatory mechanisms to food intake }\end{array}$ & $\begin{array}{l}\text { Not once, less than once a week, once a } \\
\text { week, two or more times a week }\end{array}$ & $\begin{array}{l}\text { Ferreira \& } \\
\text { Veiga } 49\end{array}$ \\
\hline Promptness to behavior change & $\begin{array}{c}\text { Transtheoretical model: eating pattern, } \\
\text { fruit and vegetable consumption, } \\
\text { physical activity }\end{array}$ & $\begin{array}{l}\text { Preconception, contemplation, preparation, } \\
\text { action, and maintenance }\end{array}$ & $\begin{array}{l}\text { Prochaska } \\
\text { et al. } 50\end{array}$ \\
\hline \multirow[t]{2}{*}{ Self-assessment of health status } & Health status & Very good, good, regular, bad, and very poor & $\begin{array}{l}\text { Secretaria } \\
\text { de Vigilância } \\
\text { em Saúde, } \\
\text { Ministério da } \\
\text { Saúde } 52\end{array}$ \\
\hline & Reported morbidity & $\begin{array}{c}\text { Hypertension or high blood pressure, } \\
\text { diabetes, high serum cholesterol or } \\
\text { triglycerides, none of the conditions, others, } \\
\text { and which ones }\end{array}$ & $\begin{array}{l}\text { Secretaria } \\
\text { de Vigilância } \\
\text { em Saúde, } \\
\text { Ministério da } \\
\text { Saúde } 52\end{array}$ \\
\hline
\end{tabular}

24hR: 24-hours dietary recall; ABEP: Brazilian Associated of Research Companies; ESE-BR: Epworth Sleepiness Scale-Brazil; IBGE: Brazilian Institute of Geography and Statistics; IPAQ: International Physical Activity Questionnaire; PHQ-9: Patient Health Questionnaire-9; PSQI-BR: Pittsburg Sleep Quality Index-Brazil;

* Variables obtained for the years prior and after admission to the university. 


\section{- Consumption of alcoholic beverages and smoking}

Alcohol consumption is evaluated regarding the experimentation (investigating whether a student had at least one drink of any alcoholic beverage in life), consumption of alcohol in the last 30 days, and the excessive consumption of alcoholic beverages (five or more drink doses for men, and four or more for women, in a single occasion) in the last 30 days 27 . In addition, the intake of ethanol (in $\mathrm{mg}$ ) is estimated considering the consumption of alcoholic beverage in the seven days before the interview, according to the average alcohol content of each type of drink as proposed by Ferreira et al. 28.

Concerning tobacco experimentation, the students are classified into two groups: students who never tried tobacco and those who already did. They are asked about the age at which they tried it for the first time. The status "current smoking" is attributed to students who mention having smoked on at least one day in the last 30 days 29 . Additionally, information on the time of exposure to tobacco and the number of cigarettes smoked per day are collected, as proposed by the smoking cessation guidelines 30 .

Information on the use of tobacco and alcohol in the year prior to admission in the university are obtained by means of yes/no questions and on how many days per month, on average, did the student drink at least one dose of alcoholic beverage.

\section{- Anthropometric measurements and blood pressure}

Anthropometric measurements are taken following the techniques recommended by Gordon et al. 31 . The weight and body fat percentage are measured using a body composition analyzer Tanita UM-080 (Tanita, Arlington Heights, USA), which has $150 \mathrm{~kg}$ capacity and a $0.1 \mathrm{~kg}$ variation. Their height is measured with portable Sanny stadiometer (ES 2040. American Medical do Brasil Ltda, São Paulo, Brazil), which measures a maximum length of $210 \mathrm{~cm}$ and has a $1 \mathrm{~mm}$ variation. Waist and neck circumference are measured by following the techniques of Callaway et al. 32, with an inextensible tape measure. Height, and waist and neck circumferences are measured twice, and the mean value obtained is considered the final measure if the difference between both measurements does not exceed $0.5 \mathrm{~cm}$ (height) or $1 \mathrm{~cm}$ (waist and neck circumferences). If the difference exceeds these limits, the measures will be taken again. Weight and height data were self-reported for the period prior to university admission. Weight status will be classified based on the body mass index (BMI - body mass/height2), according to the World Health Organization's (WHO) criteria 33,34.

Blood pressure is measured using an OMRON HEM-742 automatic monitor (OMRON Corporation, Kyoto, Japan), validated for adolescents and adults 35,36. Three measurements of blood pressure are taken, with five-minute intervals. The prevalence of hypertension is estimated according to the student age group. The guidelines of the Second Task Force on Blood Pressure Control are used to classify blood pressure in adolescents. It defines that systolic and/or diastolic blood pressure below the 90th percentile is considered as "normal", levels between the 90 and 95 percentiles as "prehypertension", and above the 95th percentile as "hypertension", according to the reference tables by gender, age, and height 37 . The criteria established by the Brazilian guidelines on hypertension is considered, which defines hypertension in adults as a systolic pressure $>140 \mathrm{mmHg}$ and/or a diastolic pressure $>90 \mathrm{mmHg} 38$.

\section{- Lipid and glycemic profile}

The capillary levels of cholesterol, triglycerides, and glucose will be assessed using a portable Accutrend Plus system validated by Eizerik et al. 39 . A drop of capillary blood of about $10 \mu \mathrm{l}$ will be collected from the pulp of the individuals' index finger and subsequently deposited on reagent test strips to be read by the digital device. The exam results will be provided by the equipment soon after collection. Cut-off points for teenagers 40,41 and adults 42 are used to classify the levels of glucose, cholesterol, and triglycerides. The metabolic profile will be evaluated by the presence of metabolic syndrome markers, which will be defined based on the recommendations of the International Diabetes Federation Task Force on Epidemiology and Prevention 43. 


\section{- Body image and self-perception of weight status}

A Stunkard Silhouette Scale 44 is being used to investigate body image. It features a set of nine drawings of male and female silhouettes by body size. Participants are asked to choose the picture that most closely matches their appearance at the time of research, the one they would like to have, and the one they consider to be the healthiest. The self-perception of weight status for which respondents must answer whether they consider their weight normal, above, or below normal is also being investigated.

\section{- Assessment of sleep habits}

Questions standardized and adapted for the Brazilian population are used to assess sleep habits, disturbances, and quality, specially the Pittsburgh Sleep Quality Index (PSQI) and the Epworth Sleepiness Scale (ESE). Both were adapted to the Brazilian population (PSQI-BR) and showed high degree of internal consistency 45,46 .

\section{- Emotional stress and depression}

The perceived stress will be evaluated by the 10-item version of the Perceived Stress Scale, validated for the Brazilian population 47. The Patient Health Questionnaire-9(PHQ-9), also validated for the Brazilian population 48 , is used to track major depressive episodes.

\section{- Disordered eating habits}

A simplified questionnaire proposed by Ferreira et al. 49 is used to investigate disordered eating habits. The questionnaire investigates the frequency of binge eating and methods to control weight gain, or possible compensatory mechanisms to excessive food intake, such as a diet that is too restrictive or fasting. For each question, there are four alternatives ranging from never to two or more times a week in the last three months.

\section{- Stages of behavior change}

The transtheoretical model assists in understanding behavioral changes 50 by identifying five readiness stages for behavior change, which is assessed by asking the participant to choose from five options the phrase that best describes their willingness to change their diet, fruit and vegetables consumption, and practice of physical activity 51 .

\section{- Self-assessment of health status}

The self-assessment of health status is performed through the question: "In comparison with people of your age, how do you rate your state of health?", and the presence of self-reported morbidities was investigated based on questions used by the Risk and Protective Factors Surveillance System for Chronic Non-Comunicable Diseases through Telephone Interview (VIGITEL) 52.

\section{- University food environment}

The location of all food retail businesses situated within a 400-meter (a quarter of mile) perimeter of the university were identified, and the data was inserted in a Geographic Information System in order to count the food sales establishments and perform a spatial analysis of the data.

\section{Baseline study and cohort follow-up in 2015 and 2016}

At the UFMT, campus Cuiabá, 812 students joined the 21 full-time courses in the first semester of the academic year 2015. Of these, 81 students abandoned the course before the data collection in the baseline survey, and 132 students did not fit the study inclusion criteria. Therefore, 599 students were 
found to be eligible for the study. Of these, 46 students (7.7\%) refused to participate, and 58 students (9.7\%) could not be located during the period of the questionnaire application. Thus, 495 students (82.6\%) were included in the study. In the follow-up of these students, which took place in the first semester of the academic year 2016, 23 students (4.6\%) suspended their registration; 51 students (10.3\%) quit the course; 13 students (2.6\%) transferred to another course, not selected for the research; 27 students (5.4\%) refused to continue participating in the research, and 33 students (6.7\%) were not located. In the end, 348 students were followed up, representing $70.3 \%$ of the enrolled participants and $58.1 \%$ of the eligible students (Figure 2). Follow-up losses for the 2015 cohort in 2016 were not significant for sex, age, skin color, and economic category (chi-square test; p > 0.05) (Table 2).

\section{Figure 2}

Flowchart for the study participants' inclusion. Longitudinal Study on Lifestyle and Health of University Students (ELESEU), Cuiabá, Mato Grosso State, Brazil.

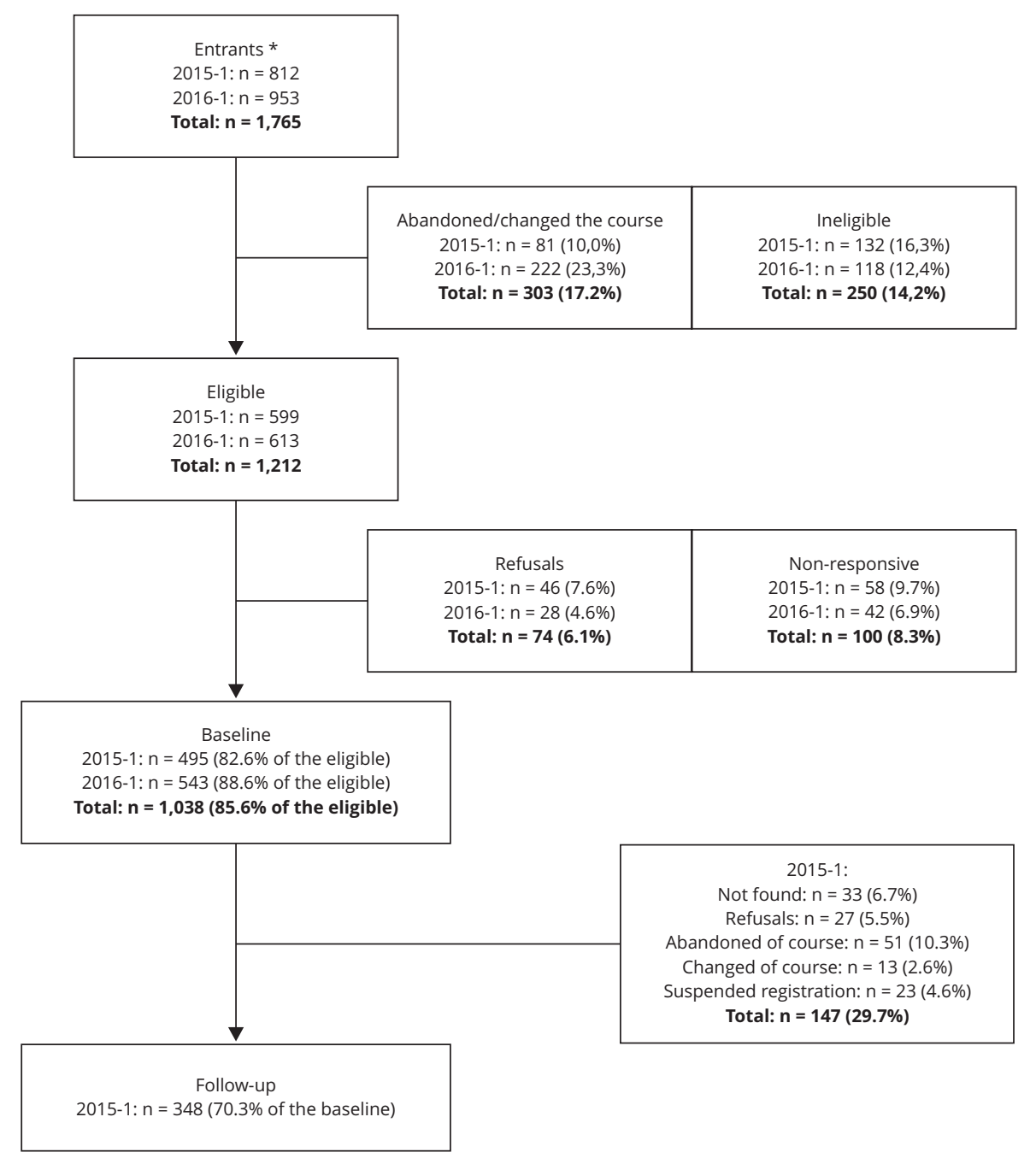

\footnotetext{
* Enrolled at the beginning of the semester in full-time courses at the Mato Grosso Federal University, Cuiabá, Mato
} Grosso State, Brazil. 
Characteristics of the full-time courses college students included in the baseline in 2015-1 (tracked in 2016) and 2016-1. Longitudinal Study on Lifestyle and Health of University Students (ELESEU). Cuiabá, Mato Grosso State, Brazil.

\begin{tabular}{|c|c|c|c|c|c|c|}
\hline & \multicolumn{4}{|c|}{ Cohort 2015} & \multirow{2}{*}{\multicolumn{2}{|c|}{$\begin{array}{l}\text { Cohort } 2016 \\
\text { Baseline ** }\end{array}$}} \\
\hline & \multicolumn{2}{|c|}{ Baseline } & \multicolumn{2}{|c|}{ Follow-up * } & & \\
\hline & $\mathbf{n}$ & $\%$ & $\mathbf{n}$ & $\%$ & $\mathbf{n}$ & $\%$ \\
\hline Total & 495 & 100 & 348 & 100 & 543 & 100 \\
\hline \multicolumn{7}{|l|}{ Gender } \\
\hline Male & 267 & 54 & 179 & 51 & 262 & 48 \\
\hline Female & 228 & 46 & 169 & 49 & 281 & 52 \\
\hline \multicolumn{7}{|l|}{ Age group (years) } \\
\hline $16-17$ & 125 & 25 & 93 & 27 & 76 & 14 \\
\hline $18-19$ & 264 & 53 & 185 & 53 & 353 & 65 \\
\hline$\geq 20$ & 106 & 21 & 70 & 20 & 114 & 21 \\
\hline \multicolumn{7}{|l|}{ Skin color/race } \\
\hline White & 203 & 41 & 145 & 42 & 213 & 39 \\
\hline Black & 55 & 11 & 39 & 11 & 64 & 12 \\
\hline Brown/Yellow/Indian & 237 & 48 & 164 & 47 & 264 & 49 \\
\hline \multicolumn{7}{|l|}{ Economic class } \\
\hline A (higher) & 99 & 21 & 71 & 30 & 93 & 18 \\
\hline B & 234 & 48 & 176 & 51 & 258 & 49 \\
\hline C-D and E (lower) & 151 & 31 & 98 & 28 & 179 & 34 \\
\hline \multicolumn{7}{|c|}{$\begin{array}{l}\text { Education of the head of the family } \\
\text { (years) }\end{array}$} \\
\hline$<9$ & 75 & 16 & 50 & 14 & 88 & 18 \\
\hline $9-12$ & 191 & 40 & 132 & 38 & 170 & 35 \\
\hline$>12$ & 218 & 45 & 163 & 47 & 233 & 48 \\
\hline \multicolumn{7}{|l|}{ Mother's education (years) } \\
\hline$<9$ & 61 & 12 & 38 & 11 & 65 & 12 \\
\hline $9-12$ & 197 & 40 & 133 & 38 & 210 & 39 \\
\hline$>12$ & 232 & 47 & 174 & 50 & 262 & 49 \\
\hline
\end{tabular}

* There was no differential loss according to the variables' categories analyzed;

** Comparing the 2015 and 2016 baselines, the only significant difference was for the variable "age group" ( $p<0,01)$.

In the first semester of the academic year 2016, 953 students joined the 21 full-time courses. Of these, 160 quit the course before the data collection of the baseline survey, and 118 students did not fit the study inclusion criteria. Six hundred and seventy-five students were eligible for the study. Of these, 62 students (9.2\%) transferred to another course that was not offered on a full-time basis, 28 students (4.1\%) refused to participate in the research, and 42 students (6.2\%) were not located during the period of the questionnaire application. Thus, 543 students $(80.4 \%)$ were included in the study (Figure 2).

\section{Discussion}

The ELESEU was designed to evaluate the impact of college life on behaviors regarding students' lifestyles and health conditions. Assessing lifestyle and health conditions-related factors based on tools and indicators widely used in national and international surveys will enable the collection of reliable data, allowing the comparability of results. Other publications describe similar studies performed in Brazil 53,54, the United States 55, Canada 56, and Spain 57.

Brito et al. 54 evaluated changes in the students' lifestyle during the first two years of five undergraduate courses at the Teacher Training Center in the Federal University of Recôncavo of Bahia, in 
the Brazilian Northeast. The used instrument comprised 25 indicators related to family and friends, work, physical activity, nutrition, tobacco and alcohol toxicity, stress, sleep, and behaviors such as safe sex and the use of safety belts ${ }^{54}$. The Monitoring of Indicators of Health and Quality of Life of Academics (MONISA) study, also developed with university students from the state of Bahia, aims at monitoring and characterizing the indicators of lifestyle, environment, and learning conditions in students enrolled in all courses (including day and night shifts) for a ten-year period, starting in 2010, with biannual evaluations 53 .

There are similar studies developed in the United States, Canada, and Spain. A study called Burn \& Earn was carried out in a public university in the northeast of the United States, which examined the weight trajectory of students throughout 4 years of college. The first assessment was performed before the first school year, in 2011, and focused on physical activity, height, and change of weight. During the first year, height and weight measurements were taken four times. One measurement was taken at the beginning, and another one was taken at the end of each semester. The last collection occurred in 2015, and it evaluated anthropometric data and information on the health behavior of individuals 55 .

Students from six Canadian universities were evaluated, using measurements taken at six different moments, on body weight, height, depression, attitudes, and food consumption behaviors. The first assessment took place prior to the students entering at the university, and the last one took place in the fourth year of their courses 56 . A study conducted in Spain aimed to determine changes in students' body weight during the first three years of university. Data collection was carried out using a self-administered questionnaire and taking measurements of weight and height 57 .

ELESEU preliminary data from the first two surveys showed that more than $80 \%$ of the eligible students were evaluated, and a considerable proportion (about $70 \%$ of them) was tracked in the second assessment. It is noteworthy that, in the 2015 cohort, there were no significant differences in demographic and socioeconomic characteristics among students followed up and those who were lost to follow-up. The follow-up rate (70.3\%) was comparable to that observed among American college students (73.5\%) 56 and higher than that found in a study performed in 23 universities in England (53\%) 58 and a study carried out in Brazil (50\%) 54 .

The sample loss observed in the ELESEU follow-up is coherent with the increasing number of unfilled vacancies in the Brazilian federal universities 59 and is due to dropouts and transfers to other courses or universities.

Among the studies found in the literature, ELESEU is the only one of census type that evaluates students annually. In the baseline, the questionnaire included questions on health and nutrition in the year prior to entering the university. Moreover, focusing on students from full-time courses in several areas of knowledge allows exploring the influence of the university environment on students' lifestyle and health conditions because of the longer periods spent in campus compared to those enrolled in part-time courses. Another strong feature of the ELESEU is the cohort with a dynamic population since the nature of some exposure factors is variable, so this strategy seems to be the most appropriate to investigate the risk factors and outcomes analyzed 60 .

Because it is a cohort study carried out during an extended period, losses to follow-up are an important challenge; therefore, all efforts were put to minimize these losses, for example, intensive search for the students using different means of communication such as phone calls, social media contacts etc. In addition, the study was conducted without any external financial support, and there was the collaboration of the university community in the data collection (faculty, staff, undergraduate and graduate students, and the university administration).

As centers of learning and research, universities have the potential to develop and apply health knowledge. These institutions can develop critical understanding and sense of social responsibility. Thus, they would be able to commit to health in their culture and organizational practice through appropriate policies and management.

A particular aspect of the UFMT that should be put into perspective in the data analysis of this study is the fact that this university has been implementing policies for the expansion of students' vacancies, admissions, and stay in higher education. In 2007, the National Program of Student Assistance was implemented, aiming to "expand and democratize the access and permanence conditions of young people in the federal higher education" 61. This program provides financial support for housing, food, 
transportation, health care, digital inclusion, culture, sports, children's daycare, and pedagogical help to low-income undergraduate students enrolled at Federal Universities. In addition, since 2012, UFMT has allocated $50 \%$ of its vacancies to students from public schools or from low-income families, or to students that declare themselves as black, mulatto (pardo) or from native populations, and to people with disabilities, in accordance with the legislation on admission to public universities 62 . This study can provide indicators to evaluate the public policies implemented in the system of Brazilian public universities.

The results of ELESEU may indicate trends related to health among college students and support planning the future health promotion strategies and the quality of life improvement for this specific group. This research intends to contribute for the identification of factors that influence changes in food, nutrition, and metabolic condition of college students. The results arising from this study may be applied in both local initiatives as national intervention programs, to foster healthy lifestyle behaviors among students.

\section{Contributors}

P. S. Nogueira contributed to the design of the study, data collection, statistical analysis and interpretation of results, design, writing and final revision of the manuscript. M. G. Ferreira contributed to the design of the study, statistical analysis and interpretation of results, design, writing and final revision of the manuscript. P. R. M. Rodrigues, A. P. Muraro and R. A. Pereira contributed to the design of the study, analysis and interpretation of results, design, writing and final revision of the manuscript. L. P. Pereira collaborated in the acquisition and statistical analysis of data, and critical review of the manuscript.

\section{Acknowledgments}

This study was funded by the Research Support Foundation of the State of Mato Grosso through a $\mathrm{PhD}$ grant (P. S. Nogueira; process 149545/2014) and by the Coordination of Improvement of Higher Education Personnel through a post-doctorate (P. R. M. Rodrigues; process 23038.006957/2014-41). However, both FAPEMAT and Capes had no role in the design, analysis or writing of this manuscript and the authors have no conflicts of interest to report.

\section{References}

1. Instituto Brasileiro de Geografia e Estatística. Síntese de indicadores sociais: uma análise das condições de vida da população brasileira. Rio de Janeiro: Instituto Brasileiro de Geografia e Estatística; 2016.

2. Vadeboncoeur C, Townsend N, Foster C. A meta-analysis of weight gain in first year university students: is freshman 15 a myth? BMC Obes $2015 ; 2: 22$.

3. Wengreen HJ, Moncur C. Change in diet, physical activity, and body weight among young-adults during the transition from high school to college. Nutr J 2009; 8:32.

4. Cheng SH, Shih C-C, Lee IH, Hou Y-W, Chen $\mathrm{KC}$, Chen K-T, et al. A study on the sleep quality of incoming university students. Psychiatry Res 2012; 197:270-4.

5. Soares AM, Pereira M, Canavarro JP. Saúde e qualidade de vida na transição para o ensino superior. Psicol Saúde Doença 2014; 15 : 356-79.

6. Deforche B, Van Dyck D, Deliens T, De Bourdeaudhuij I. Changes in weight, physical activity, sedentary behaviour and dietary intake during the transition to higher education: a prospective study. Int J Behav Nutr Phys Act 2015; 12:16.

7. Strazzullo P, D’Elia L, Kandala NB, Cappuccio FP. Salt intake, stroke, and cardiovascular disease: meta-analysis of prospective studies. BMJ 2009; 339:b4567.

8. Trovato GM. Behavior, nutrition and lifestyle in a comprehensive health and disease paradigm: skills and knowledge for a predictive, preventive and personalized medicine. EPMA J 2012; 3:8. 
9. Malik VS, Willett WC, Hu FB. Global obesity: trends, risk factors and policy implications. Nat Rev Endocrinol; 2013; 9:13-27.

10. Valdes-Badilla P, Godoy-Cumillaf A, HerreraValenzuela T, Durán-Agüero S. Comparación en hábitos alimentarios y condición física entre estudiantes de educación física y otras carreras universitárias. Nutr Hosp 2015; 32:829-36.

11. Juhola J, Magnussen CG, Viikari JSA, Kähönen M, Hutri-Kähönen N, Jula A, et al. Tracking of serum lipid levels, blood pressure, and body mass index from childhood to adulthood: the Cardiovascular Risk in Young Finns Study. J Pediatr 2011; 159:584-90.

12. Joshi SM, Katre PA, Kumaran K, Joglekar C, Osmond C, Bhat DS, et al. Tracking of cardiovascular risk factors from childhood to young adulthood: the Pune Children's Study. Int J Cardiol 2014; 175:176-8.

13. Feliciano-Alfonso JE, Mendivil CO, Ariza IDS, Pérez CE. Cardiovascular risk factors and metabolic syndrome in a population of young students from the National University of Colombia. Rev Assoc Med Bras (1992) 2010; 56:293-8.

14. Sousa TF, José HPM, Barbosa AR. Condutas negativas à saúde em estudantes universitários brasileiros. Ciênc Saúde Coletiva 2013; 18:3563-75.

15. Dias FDSL, Passos MEA, Carmo MDGT, Lopes MLM, Mesquita VLV. Fatty acid profile of biscuits and salty snacks consumed by Brazilian college students. Food Chem 2015; 171:351-5.

16. Greaney ML, Less FD, White AA, Dayton SF, Riebe D, Blissmer B, et al. College students' barriers and enablers for healthful weight management: a qualitative study. J Nutr Educ Behav 2009; 41:281-6.

17. Lytle LA. Measuring the food environment state of the science. Am J Prev Med 2009; 36 (4 Suppl):S134-44.

18. Roy R, Kelly B, Rangan A, Allman-Farinelli M. Food environment interventions to improve the dietary behavior of young adults in tertiary education settings: a systematic literature review. J Acad Nutr Diet 2015; 115:1647-81.

19. Instituto Nacional de Estudos e Pesquisas Educacionais Anísio Teixeira. Censo da educação superior, 2015. Brasília: Instituto Nacional de Estudos e Pesquisas Educacionais Anísio Teixeira; 2015.

20. Instituto Brasileiro de Geografia e Estatística. Características étnico-raciais da população: um estudo das categorias de classificação de cor ou raça: 2008. Rio de Janeiro: Instituto Brasileiro de Geografia e Estatística; 2011.

21. Associação Brasileira de Empresas de Pesquisa. Critérios de classificação econômica do Brasil. São Paulo: Associação Brasileira de Empresas de Pesquisa; 2015.

22. Kearney M, Kearney JM, Dunne A, Gibney MJ. Sociodemographic determinants of perceived influences on food choice in a nationally representative sample of Irish adults. Public Health Nutr 2000; 3:219-26.
23. Estima CCP. Por que os adolescentes comem o que comem? Determinantes do consumo alimentar [Doctoral Dissertation]. São Paulo: Universidade de São Paulo; 2012.

24. Conway JM, Ingwersen LA, Moshfegh AJ. Accuracy of dietary recall using the USDA fivestep multiple-pass method in men: an observational validation study. J Am Diet Assoc 2004; 104:595-603.

25. Matsudo S, Araujo T, Matsudo V, Andrade D, Andrade E, Oliveira LC, et al. Questionário Internacional de Atividade Física (IPAQ): estudo de validade e reprodutibilidade no Brasil. Rev Bras Ativ Fís Saúde 2001; 6:5-18.

26. Hickman M, Roberts C, Matos MG. Exercise and leisure-time activities. In: Currie C, Hurrelmann K, Settertobulte W, Smith R, Todd J, editors. Health and health behaviour among young people. Copenhagen: World Health Organization Regional Office for Europe; 2000. p. 73-82.

27. Moura EC, Malta DC. Alcohol consumption in the Brazilian adult population: sociodemographic characteristics and trend. Rev Bras Epidemiol 2011; 14:61-70.

28. Ferreira MG, Valente JG, Gonçalves-Silva RMV, Sichieri R. Consumption of alcoholic beverages and abdominal adiposity in blood donors. Rev Saúde Pública 2008; 42:1067-73.

29. World Health Organization. Guidelines for controlling and monitoring the tobacco epidemic. Geneva: World Health Organization; 1998.

30. Reichert J, Araújo AJ, Gonçalves CMC, Godoy I, Chatkin JM, Sales MPU, et al. Diretrizes para cessação do tabagismo - 2008. J Bras Pneumol 2008; 34:845-80.

31. Gordon CC, Chumlea WC, Roche AF. Stature, recumbent length, and weight. In: Lohman TG, Roche AF, Martorell R, editors. Anthropometric standardization reference manual. Champaign: Human Kinetics; 1988. p. 3-8.

32. Callaway TG, Lohman CW, Chumlea AF, Roche WC, Bouchard R, Martoreli C, et al. Circumferences. In: Lohman TG, Roche AF, Martorell R, editors. Anthropometric standardization reference manual. Champaign: Human Kinetics; 1988. p. 39-54.

33. World Health Organization. Physical status: the use and interpretation of anthropometry. Geneva World Health Organization; 1995. (WHO Technical Report Series, 854).

34. World Health Organization. Growth reference data for 5-19 years: body mass index-for-age, length/height-for-age and weight-for-height. Geneva: World Health Organization; 2007.

35. Coleman AJ, Steel SD, Ashworth M, Vowler SL, Shennan A. Accuracy of the pressure scale of sphygmomanometers in clinical use within primary care. Blood Press Monit 2005; 10:181-8.

36. Christofaro DGD, Fernandes RA, Gerage AM, Alves MJ, Polito MD, Oliveira AR. Validation of the Omron HEM 742 Blood Pressure Monitor in Teens. Arq Bras Cardiol 2009; 92:10-5. 
37. National High Blood Pressure Education Program Working Group on High Blood Pressure in Children and Adolescents. The fourth report on the diagnosis, evaluation, and treatment of high blood pressure in children and adolescents. Pediatrics 2004; 114(2 Suppl 4th Report):555-76.

38. Sociedade Brasileira de Cardiologia; Sociedade Brasileira de Hipertensão; Sociedade Brasileira de Nefrologia. VI Diretrizes Brasileiras de Hipertensão. Arq Bras Cardiol 2010; 95 Suppl 1:1-51.

39. Eizerik DP. Análise comparativa de dois métodos de mensuração de glicose, colesterol e triglicerídeos: sangue venoso em laboratório de bioquímica e sangue capilar em dispositivo portátil Accutrend GCT ${ }^{\circledR}$ [Master's Thesis]. Rio Grande do Sul: Universidade Federal do Rio Grande do Sul; 2012.

40. Sociedade Brasileira de Cardiologia. I Diretriz de Prevenção da Aterosclerose na Infância e na Adolescência. Arq Bras Cardiol 2005; 85 Suppl 6:1-36.

41. American Diabetes Association. Diagnosis and classification of diabetes mellitus. Diabetes Care 2006; 29 Suppl 1:S43-8.

42. Xavier HT, Izar MC, Faria Neto JR, Assad MH, Rocha VZ, Sposito AC, et al. V Diretriz Brasileira de Dislipidemias e Prevenção da Ateroscleroses. Arq Bras Cardiol 2013; 101(4 Suppl 1):1-22.

43. Alberti KGMM, Eckel RH, Grundy SM, Zimmet PZ, Cleeman JI, Donato KA, et al. Harmonizing the metabolic syndrome: a joint interim statement of the International Diabetes Federation Task Force on Epidemiology and Prevention; National Heart, Lung, and Blood Institute; American Heart Association; World Heart Federation; International Atherosclerosis Society; and International Association for the Study of Obesity. Circulation 2009; 120:1640-5.

44. Stunkard AJ, Sorenson T, Schlusinger F. Use of the Danish Adoption Register for the study of obesity and thinness. In: Kety SS, Rowland LP, Sidman RL, Matthysse SW, editors. The genetics of neurological and psychiatric disorders. New York: Raven Press; 1983. p. 115-20.

45. Bertolazi AN, Fagondes SC, Hoff LS, Pedro VD, Barreto SSM, Johns MW. Validation of the epworth sleepiness scale in Portuguese for use in Brazil. J Bras Pneumol 2009; 35:877-83.

46. Bertolazi AN, Fagondes SC, Hoff LS, Dartora EG, Silva Miozzo IC, Barba MEF, et al. Validation of the Brazilian Portuguese version of the Pittsburgh Sleep Quality Index. Sleep Med 2011; 12:70-5.

47. Reis RS, Hino AAF, Rodriguez-Añez CR. Perceived stress scale reliability and validity study in Brazil. J Health Psychol 2010; 15:107-14.

48. Santos IS, Tavares BF, Munhoz TN, Almeida LSP, Silva NTB, Tams BD, et al. Sensibilidade e especificidade do Patient Health Questionnaire-9 (PHQ-9) entre adultos da população geral. Cad Saúde Pública 2013; 29:1533-43.
49. Ferreira JES, Veiga GV. Reliability (test-retest) of a simplified questionnaire for screening adolescents with risk behaviors for eating disorders in epidemiological studies. Rev Bras Epidemiol 2008; 11:393-401.

50. Prochaska JO, DiClemente CC, Norcross JC. In search of how people change: applications to addictive behaviors. Am Psychol 1992; 47:1102-14.

51. Pirzadeh A, Mostafavi F, Ghofranipour F, Feizi A. Applying transtheoretical model to promote physical activities among women. Iran J Psychiatry Behav Sci 2015; 9:e1580.

52. Secretaria de Vigilância em Saúde, Ministério da Saúde. Vigitel Brasil 2013: vigilância de fatores de risco e proteção para doenças crônicas por inquérito telefônico. Brasília: Ministério da Saúde; 2014. (Série G. Estatística e Informação em Saúde).

53. Sousa TF, Fonseca SA, José HPM, Nahas MV. MONISA study: characteristics and methodological aspects. Rev Bras Epidemiol 2012; 15:904-7.

54. Brito BJQ, Gordia AP, Quadros TMB. Estilo de vida de estudantes universitários: estudo de acompanhamento durante os dois primeiros anos do curso de graduação. Medicina (Ribeirão Preto) 2016; 49:293-302.

55. Pope L, Hansen D, Harvey J. Examining the weight trajectory of college students. J Nutr Educ Behav 2017; 49:137-41.

56. Girz L, Polivy J, Provencher V, Wintre MG, Pratt MW, Mark Pancer S, et al. The four undergraduate years. Changes in weight, eating attitudes, and depression. Appetite 2013; 69:145-50.

57. Ruiz MNS, Ontoso IA, Armayor NC, GuillénGrima F, Mendoza JH, Monzo IS, et al. Modificación del peso corporal de los estudiantes universitarios durante los tres primeros años de universidad. Nutr Hosp 2015; 31:2400-6.

58. Vadeboncoeur C, Foster C, Townsend N. Freshman 15 in England: a longitudinal evaluation of first year university student's weight change. BMC Obes 2016; 3:45.

59. Veloso TCMA, Silva MGM, Nogueira PS. Programas de expansão e ingresso nas universidades federais: a permanência do estudante em questão. In: Jezine E, Branco UVC, organizadores. Educação superior: saberes, tecnologias e desafios para a formação. João Pessoa: Editora CCTA; 2017. p. 103-21.

60. Coeli CM, Faerstein E. Estudos de coorte. In: Medronho RA, Block KV, Luiz RR, Werneck GL, organizadores. Epidemiologia. 2a Ed. Rio de Janeiro: Editora Atheneu; 2009. p. 237-50.

61. Ministério da Educação. Portaria Normativa no 39, de 12 de dezembro de 2007. Institui o Programa Nacional de Assistência Estudantil PNAES. Diário Oficial da União 2007, 13 dez.

62. Brasil. Lei no 12.711, de 29 de agosto de 2012. Dispõe sobre o ingresso nas universidades federais e nas instituições federais de ensino técnico de nível médio e dá outras providências. Diário Oficial da União 2012; 30 ago. 


\section{Resumo}

O ingresso na universidade, para o aluno, pode provocar mudanças significativas no perfil de exposição a riscos para a saúde. $O$ artigo tem como objetivo descrever o delineamento e procedimentos metodológicos adotados pelo Estudo Longitudinal sobre Estilo de Vida e Saúde em Estudantes Universitários (ELESEU). O estudo tem como base uma coorte dinâmica de estudantes universitários matriculados em tempo integral em uma universidade pública no Estado de Mato Grosso, Brasil. A coorte teve início em 2015 e terá quatro anos de seguimento, com a conclusão prevista para 2018. Um questionário auto-administrado contém perguntas sobre características demográficas e socioeconômicas e informações sobre condições de saúde e fatores de risco, tais como estilo de vida, estresse percebido, sintomas de depressão, imagem corporal, comportamentos de risco para transtornos alimentares, auto-percepção da saúde e qualidade da dieta e outras questões relacionadas à nutrição e saúde. Também são registradas medidas antropométricas e de pressão arterial. São coletados dois recordatórios alimentares de 24 horas e medidas de colesterol, triglicerídeos e glicose capilar em 50\% dos estudantes. Em 2015, 495 participantes (82,6\% dos estudantes elegíveis) foram avaliados no estudo de linha de base. Destes, 348 (70,3\%) foram reavaliados em 2016. Em 2016, 566 participantes foram incluídos na coorte ( $81 \%$ dos estudantes elegíveis). O estudo ajudará a identificar fatores que possam influenciar mudanças na saúde nutricional e estado metabólico de adultos jovens durante a vida universitária.

Estudantes; Universidades; Estilo de Vida; Estudos Longitudinais

\section{Resumen}

La admisión a la universidad puede provocar cambios significativos en el patrón de exposición a los riesgos de salud. El objetivo de este trabajo es describir el diseño del estudio y los procedimientos metodológicos adoptados en el Estudio Longitudinal sobre Estilo de Vida y Salud de Estudiantes Universitario (ELESEU). Este estudio examina una cohorte dinámica de estudiantes a tiempo completo en una universidad pública en el estado de Mato Grosso, Brasil. Esta investigación, que empezó en 2015, tendrá 4 años de seguimiento y está previsto que finalice en 2018. Se utiliza un cuestionario autoadministrado, que contiene preguntas respecto a las características demográficas $y$ socioeconómicas, e información sobre condiciones de salud y factores de riesgo tales como: estilo de vida, estrés percibido, síntomas de depresión, imagen corporal, riesgo de desórdenes en el comportamiento alimenticio, autoevaluación de salud y calidad de la dieta, así como otros asuntos relacionados con la nutrición y la salud. Las medidas antropométricas, así como la toma de presión arterial también fueron recogidas. Se recogieron dos encuestas alimentarias de 24-horas, análisis de colesterol, triglicéridos, y muestras de glucosa capilar en un 50\% de los estudiantes. En 2015, 495 participantes (un 82,6\% de los estudiantes elegibles) fueron evaluados en este estudio de referencia. De ellos, a 348 (un 70,3\%) se les realizó un seguimiento en 2016. En 2016, 566 participantes fueron incluidos en la cohorte ( $81 \%$ de los estudiantes elegibles). Este estudio nos ayudará a identificar los factores que tal vez influencien en cambios nutricionales, de salud, y metabólicos en el estado de adultos jóvenes durante su vida universitaria.

Estudiantes; Universidades; Estilo de Vida; Estudios Longitudinales
Submitted on 25/Aug/2017

Final version resubmitted on $03 / \mathrm{Nov} / 2017$

Approved on 04/Dec/2017 